\title{
PERLINDUNGAN HUKUM TERHADAP MEREK DAGANG TERKENAL ATAS TINDAKAN PASSING OFF PADA PRAKTEK PERSAINGAN USAHA
}

\author{
Ahmad Yakub Sukro \\ Magister Ilmu Hukum, Fakultas Hukum, Universitas Diponegoro \\ yakub.sukro@gmail.com \\ DOI: https://doi.org/10.29313/sh.v16i1.5130
}

\begin{abstract}
ABSTRAK
Dalam aktivitas bisnis, tidak sedikit dari para pelaku usaha mencari jalan pintas untuk memanfaatkan nilai ekonomis merek terkenal dan memiliki reputasi secara melawan hukum sehingga pemilik merek terkenal secara hukum dilanggar haknya. Tulisan ini bertujuan untuk mengetahui perlindungan hukum merek dagang terkenal atas tindakan passing off dan bentuk-bentuk pelanggaran passing off. Metode penelitian menggunakan pendekatan yuridis normatif dengan teknik analisis data secara kualitatif yang menggunakan data sekunder. Perlindungan hukum merek dagang terkenal atas tindakan passing off belum memadai karena dalam undangundang larangan monopoli dan persaingan usaha tidak sehat atau hukum anti monopoli pengaturan melalui Undang-Undang Nomor 5 Tahun 1999 Tentang Larangan Monopoli dan Persaingan Usaha Tidak Sehat tindakan passing off tidak diatur secara rigid. Bentuk pelanggaran merek dagang terkenal melalui tindakan passing of apabila memenuhi 3 (tiga) kriteria. Pertama, adanya reputasi pelaku usaha memiliki reputasi bisnis yang baik di mata publik dan cukup dikenal oleh umum. Keadaan demikian dimanfaatkan oleh pesaing pelaku usaha secara melawan hukum. Kedua, adanya misrepresentasi apabila ada pelaku usaha lain mendompleng merek yang sama maka publik mudah terkecoh (misleading) atau terjadi kebingungan (confusion) dalam memilih produk. Ketiga, terdapat kerugian yang timbul akibat tindakan pendomplengan atau pemboncengan dengan iktikad tidak baik menggunakan merek yang mirip dengan merek yang telah dikenal sehingga terjadi kekeliruan memilih produk oleh publik (publik misleading).
\end{abstract}

Kata Kunci: Hak Kekayaan Intelektual, Passing Off.

\section{ABSTRACT}

In business activities, not a few of business people are looking for shortcuts to exploit the economic value of well-known brands and have a reputation against the law so that the owner of a well-known brand is legally violated. This paper aims to find out the legal protection of a well-known trademark for passing off and other forms of passing off. The research method uses a normative juridical approach with qualitative data analysis techniques that use secondary data. Famous trademark legal protection for passing off is not sufficient because in the monopoly prohibition law and unfair 
business competition or anti-monopoly law regulation through Law No. 5 of 1999 concerning Prohibition of Monopoly and Unfair Business Competition the act of passing off is not regulated rigid. Forms of infamous trademark violations through passing of actions if they meet 3 (three) criteria. First, the reputation of business actors has a business reputation that is good in the public eye and quite well known to the public. Such a situation is exploited by competitors of businesses in an unlawful manner. Second, there is a misrepresentation if there are other business actors composing the same brand so that the public is easily misleading (misleading) or there is confusion in choosing the product. Third, there is a loss arising from the accompaniment or hijacking action in the intention of not using a brand that is similar to a known brand so that there is a mistake in choosing products by the public. (public misleading).

Keywords: Insurance Claims, Legal Sanctions, Financial Services Authority.

\section{A. PENDAHULUAN}

\section{Latar Belakang Masalah}

Dalam perdagangan barang atau saja, merek sebagai salah satu bentuk karya intelektual yang penting bagi kelancaran dan peningkatan perdagangan barang atau jasa. Merek memiliki nilai yang strategis dan penting bagi produsen maupun konsumen. ${ }^{1}$ Penggunaan merek merupakan kunci dari suksesnya menggiatkan usaha perdagangan yang dilakukan oleh suatu korporasi dalam memenangkan persaingan usaha di pasar yang menjadi target dimana produk tersebut didistribusikan. Selain itu, fungsi dari merek sendiri merupakan selain dari suatu aspek dari hasil karya intelektual yang memiliki nilai ekonomis juga merupakan suatu simbol atau tanda yang menjadikan penanda dari suatu produk yang dihasilkan oleh suatu badan usaha ataupun perusahaan sehingga dapat dikenali oleh masyarakat selaku konsumen atas produk tersebut.

Merek sendiri dalam hal posisinya pada persaingan usaha memiliki perannya tersendiri yang cukup strategis dalam membedakan antara produk satu dengan produk yang lain yang memiliki bentuk serupa akan tetapi dihasilkan oleh suatu badan usaha yang berbeda. Dari pokok pikiran tersebut sudah semestinya melekat dari apa yang telah dihasilkan oleh produsen dengan produk yang memiliki bentuk dan jenis serupa akan

\footnotetext{
${ }^{1}$ Rifky Ardian Nugroho, Budi Santoso, Siti Mahmudah.Perlindungan Hukum Pemegang Hak Merek Dagang Terkenal Asing (Well Known Mark) dari Tindakan Passing Off (Studi Sengketa GS Atas Nama GS Yuasa Corporation). Semarang; Diponegoro Law Journal. Volume 5, Nomor 3, Tahun 2016. Hlm. 2.
} 
tetapi melalui pembedaan merek dagang tersebut tersirat kualitas dan spesifikasi yang berbeda pula sehingga memiliki daya pembeda atas merek yang berbeda dengan produk yang sama dalam persaingan usaha atas banyak merek dagang di pasar.

Bagi konsumen, merek selain mempermudah pengidentifikasian juga menjadi simbol harga diri. Masyarakat yang sudah terbiasa dengan pilihan barang dari merek tertentu, cenderung menggunakan barang dengan merek tersebut seterusnya dengan berbagai alasan karena sudah mengenal lama, terpercaya, kualitas produknya, dan lain- lain. Sehingga fungsinya merek sebagai jaminan kualitas semakin nyata, khususnya terkait dengan produk-produk bereputasi. ${ }^{2}$ Dari merek yang memiliki reputasi yang baik tersebut setidaknya mendapatkan perlindungan yang mumpuni guna menciptakan iklim persaingan usaha yang sehat dalam rangka pengakomodiran penggunaan merek pada suatu produk dagang.

Dalam dunia perdagangan sendiri setidaknya terdapat pengkategorian dari merek-merek dagang, pengkategorian tersebut merupakan bentuk tingkat level dari terkenalnya suatu merek oleh konsumen, tingkat merek tersebut diantaranya adalah merek yang memiliki standaritas pengenalan biasa (normal mark), selanjutnya merek dengan standaritas pengenalan terkenal (well-known mark) dan yang ketiga yaitu merek dengan standaritas pengenalan termasyhur (famous mark). Dari ketiga pengkategorian merek tersebut sejatinya memiliki kedudukan yang berbeda di pandangan masyarakat atas sikap konsumerisme dari produk dagang yang memiliki reputasi pengenalan merek yang berbeda-beda pula menurut 3 standaritas pengenalan merek tersebut.

Merek dagang dari suatu produk dengan jenis barang ataupun jasa tertentu sudah menjadi terkenal dengan statusnya di masyarakat sebagai bentuk hirarkis kedudukan suatu produk di mata pelanggannya, dari hal itu dan ketiga kategori tersebut juga membuat para pelaku usaha memacu aktivitas bisnisnya dalam meningkatkan level dan status merek dagang mereka di mata masyarakat

2 Muhammad Djumhana, Perkembangan Doktrin dan Teori Perlindungan Hak Kekayaan Intelektual, Citra Aditya Bakti, Bandung, 2006, hlm. 78. 
sehingga menjadikan merek tersebut termasyhur dan meningkatkan produksi atas suatu barang dan jasa. Kebutuhan adanya perlindungan hukum terhadap merek semakin berkembang dari masa ke masa setelah berkembang dan bervariasinya juga bentuk pelanggaran atas merek dagang tersebut dalam dimensi persaingan usaha tidak sehat oleh pelaku usaha perdagangan.

Merek terkenal merupakan tanda yang memiliki reputasi baik yang tinggi diantara merek-merek lain dengan kualifikasi yang tinggi dari standaritas produknya dan kualitas yang bagus juga atas produk yang dihasilkan menjadikan hal tersebut terkenal dan banyak dibutuhkan oleh masyarakat selaku konsumen atau pelanggaran atas suatu barang atau jasa. Dari aktivitas tersebutlah sejatinya banyak menimbulkan permasalahan-permasalahan yang timbul dan berkembang searah dari perkembangan dunia bisnis yang tidak mengenal batas negara ataupun batas ruang dan waktu dengan skala nasional, regional ataupun skala internasional. Pentingnya perlindungan hukum atas sebuah merek dagang juga didasarkan pada tergabungnya Indonesia ke dalam organisasi perdagangan dunia yakni World Trade Organization (WTO) yang melahirkan suatu kesepakatan bersama dalam bidang HKI (intellectual property rights) dengan produk perjanjian bernama Trade Related Aspect of Intellectual Property Rights (TRIPs).

Reputasi tinggi yang dimiliki oleh merek dagang terkenal (well-known or famous mark) tersebut dapat memicu tindakan-tindakan pelanggaran merek baik nasional maupun internasional. ${ }^{3}$ Merek terkenal harus diberikan perlindungan baik dalam skala nasional maupun internasional, karena suatu merek terkenal mengalami perluasan perdagangan melintasi batas-batas negara. ${ }^{4}$ Pelanggaran atas merek tersebut merupakan tindakan yang tidak baik dan melanggar legalitas karena terdapat unsur iktikad tidak baik atas penggunaan ataupun pendomplengan dan pemboncengan merek dagang terkenal (well-known or famous mark) dengan tanpa izin atau lisensi dari pemegang merek dagang terkenal tersebut dengan menerobos norma kesopanan dan norma hukum dalam

${ }^{3}$ Rifky Ardian Nugroho, Budi Santoso, Siti Mahmudah. 2016. Op cit. hlm. 3.

${ }^{4}$ Ibid. 
etika berbisnis pada persaingan usaha.

Tindakan pelanggaran atas merek dagang tersebut dalam kaitannya dengan pemboncengan terhadap merek dagang terkenal (well-known or famous mark) secara umum dikenal dengan tindakan Passing Off. Tindakan Passing Off terkait erat dengan apa yang disebut dengan goodwill, goodwill sering digunakan dalam arti yang bersamaan dengan kata reputasi yaitu sebagai sesuatu yang melekat delam merek dan selain itu kata goodwill sering juga diartikan sebagai "iktikad tidak baik". 5

\section{Identifikasi Masalah}

Artikel ini akan membahas bagaimana perlindungan hukum hak kekayaan intelektual (HKI) atas merek dagang terkenal di Indonesia, dan bagaimana konsekuensi hukum pelanggaran atas tindakan Passing Off dalam persaingan usaha tidak sehat.

\section{Metode Penelitian}

Metode penelitian dalam penulisan ini menggunakan pendekatan yuridis normatif karena penulis melakukan inventarisasi peraturan perundangundangan yang mengatur masalah asuransi. Spesifikasi penelitian menggunakan deskriptif analitis dengan menggambarkan suatu kenyataan dan fakta-fakta yang berkaitan dengan hukum perasuransian. Teknik analisis data menggunakan metode kualitatif karena tidak menggunakan rumus dan angka.

\section{B. PEMBAHASAN}

\section{a. Perlindungan Hukum Atas Hak Kekayaan Intelektual Atas Hak Merek Dagang Terkenal di Indonesia}

Secara substantif pengertian Hak Kekayaan Intelektual (HKI) dapat dikatakan sebagai hak atas kepemilikan sebagai karya-karya yang timbul atau lahir karena adanya kemampuan intelektualitas manusia dalam bidang ilmu pengetahuan dan teknologi. ${ }^{6}$ Sedangkan Helianti Hilman, dalam makalah yang berjudul Manfaat

\footnotetext{
${ }^{5}$ Ibid.

${ }^{6}$ Rachmadi Usman. Hukum Hak atas Kekayaan Intelektual, Perlindungan dan Dimensi Hukumnya di Indonesia, Alumni, Bandung, 2003, hlm. 2.
} 
Perlindungan Terhadap Karya Intelektual pada Sistem HaKI memberikan pengertian bahwa yang dimaksud Hak kekayaan Intelektual adalah suatu hak eksklusif yang diberikan oleh negara kepada seseorang atau sekelompok orang atau entitas untuk memegang monopoli dalam menggunakan dan mendapatkan manfaat dari karya intelektual yang mengandung HKI tersebut. ${ }^{7}$

Hak Kekayaan Intelektual ada agar dapat melindungi ciptaan serta invensi seseorang dari penggunaan atau peniruan yang dilakukan oleh pihak lain tanpa izin. ${ }^{8}$ Karya-karya intelektual tersebut apakah di bidang ilmu pengetahuan, seni, sastra, atau teknologi dilahirkan dengan mengorbankan tenaga, waktu, bahkan biaya. Sehingga perlindungan yang diberikan dalam HKI akan menjadikan sebuah insentif bagi pencipta dan inventor.

Hukum HKI merupakan sebuah hukum yang harus terus mengikuti perkembangan teknologi untuk melindungi kepentingan pencipta. Kata milik atau kepemilikan dalam HKI memiliki ruang lingkup yang lebih khusus dibandingkan dengan istilah kekayaan. Hal ini juga sejalan dengan konsep hukum perdata Indonesia yang menerapkan istilah milik atas benda yang dipunyai seseorang. ${ }^{9}$ Hak Kekayaan Intelektual terdiri dari jenis-jenis perlindungan yang berbeda, bergantung kepada objek atau karya intelektual yang dilindungi. Dalam perundingan Persetujuan Umum tentang Tarif dan Perdagangan (General Agreement on Tariff and Trade/GATT), disebutkan bahwa Hak Kekayaan Intelektual terdiri dari: Hak Cipta dan hak-hak yang berkaitan; Merek; Indikasi Geografis; Desain Industri; Paten, termasuk perlindungan varietas tanaman; Desain Tata Letak Sirkuit Terpadu; Perlindungan terhadap informasi dirahasiakan; dan Pengendalian Praktik Praktik Persaingan Curang dalam perjanjian Lisensi.

\footnotetext{
${ }^{7}$ Helianti Hilman. Manfaat Perlindungan Terhadap Karya Intelektual pada Sistem HaKI. Disampaikan pada Lokakarya Terbatas tentang "Masalah-masalah Kepailitan dan Wawasan Hukum Bisnis Lainnya". Financial Club, Jakarta, 10-11 Februari 2004, hlm. 4.

${ }^{8}$ Eddy Damian, dkk. Hak Kekayaan Intelektual (Suatu Pengantar), Alumni, Bandung, 2003, hlm. 2.

${ }^{9}$ Ahmad M. Ramli, Hak atas Kepemilikan Intelektual: Teori Dasar Perlindungan Rahasia Dagang, Mandar Maju, Bandung, 2000, hlm. 24. 
HKI pada umumnya berhubungan dengan ciptaan dan invensi yang memiliki nilai komersial. Merek sebagai salah satu produk dari karya intelektual dapat dianggap suatu asset komersial suatu perusahaan, untuk itu diperlukan perlindungan hukum untuk melindungi karya-karya intelektualitas seseorang. Kelahiran merek diawali dari temuan- temuan dalam bidang hak kekayaan intelektual lain yang saling berkaitan. Seperti dalam merek terdapat unsur ciptaan, misalnya desain logo, desain huruf atau desain angka. Ada hak cipta dalam bidang seni, sehingga yang dilindungi bukan hak cipta dalam bidang seni, tetapi yang dilindungi adalah mereknya sendiri. ${ }^{10}$

Merek sangat berharga dalam HKI karena merek dikaitkan dengan kualitas dan keinginan konsumen dalam sebuah produk atau servis. Dengan merek, seseorang akan tertarik atau tidak tertarik untuk mengkonsumsi sesuatu. Sesuatu yang tidak terlihat dalam merek dapat menjadikan pemakai atau konsumen setia dengan merek tersebut. Hal inilah yang merupakan hak milik immaterial yang terdapat dalam merek.

Pengertian merek diberbagai negara sekarang ini pada dasarnya banyak mengandung persamaan sebab mengacu kepada ketentuan Paris Convention. Dalam bahasa Indonesia, merek berarti tanda yang dipakai pada barang yang diperdagangkan oleh suatu perusahaan. Sedangkan pengertian secara yuridis, merek menurut ketentuan umum Undang-Undang Nomor 20 Tahun 2016 tentang Merek dan Indikasi Geografis, dalam Pasal 1 butir 1 disebutkan:

"Merek adalah tanda yang dapat ditampilkan secara grafis berupa gambar, logo, nama, kata, huruf, angka, susunan warna, dalam bentuk 2 (dua) dimensi dan/atau 3 (tiga) dimensi, suara, hologram, atau kombinasi dari 2 (dua) atau lebih unsur tersebut untuk membedakan barang dan/atau jasa yang diproduksi oleh orang atau badan hukum dalam kegiatan perdagangan barang dan/atau jasa."

Pengertian Merek sebagaimana diatur dalam Pasal 15 ayat (1) TRIPs

${ }^{10}$ O.K. Saidin. Aspek Hukum Hak Kekayaan Intelektual (Intellectual Property Right), Cetakan Keempat, Raja Grafindo Persada, Jakarta, 2004, hlm. 254. 
Agreement adalah sebagai berikut:

"Any sign or any combination of signs, capable of distinguishing, the goods of services of one undertaking from those of other undertakings, shall be capable of constituting a trademark. Such signs, in particular words including personal names, letters, numerals, figurative elements and combinations of colours as well as any combination of such signs, shall be eligible for registration as trademark. Where signs are not inherently capable of distinguishing the relevant goods or services, members may make registrability depend on distinctiveness acquired through use. Members may require, as a condition of registration, that signs be visually perceptible"

Berdasarkan pendapat tersebut diatas, dapat disimpulkan bahwa merek merupakan suatu tanda yang dapat menunjukkan identitas barang atau jasa, yang menjadi pembeda suatu barang atau jasa dengan barang atau jasa lainnya dihasilkan oleh seseorang, beberapa orang atau badan hukum dengan barang atau jasa yang sejenis milik orang lain, memiliki kekuatan perbedaan yang cukup, yang dipakai dalam produksi dan perdagangan.

Merek adalah suatu tanda, tetapi agar tanda tersebut dapat diterima oleh merek, harus memiliki daya pembeda, ${ }^{11}$ hal ini disebabkan pendaftaran merek, berkaitan dengan pemberian hak eksklusif yang diberikan oleh negara atas nama atau simbol terhadap suatu pelaku usaha. Untuk mempunyai daya pembeda, merek yang bersangkutan arus dapat memberikan penentuan atau "individuali sering" dari barang yang bersangkutan. ${ }^{12}$ Terjadinya perbedaan kemasyhuran suatu merek, membedakan pula tingkat derajat kemasyhuran yang dimiliki oleh berbagai merek. Ada 3 (tiga) jenis merek yang dikenal oleh masyarakat: ${ }^{13}$

1. Merek Biasa, disebut juga sebagai "normal mark", yang tergolong kepada merek biasa adalah merek yang tidak memiliki reputasi tinggi. Merek yang masuk kategori ini boleh dikatakan kurang ikut

\footnotetext{
${ }^{11}$ Suyud Margono dan Lingginus Hadi, Pembaharuan Perlindungan Hukum Merek, Novirindo Pustaka Mandiri, Jakarta, 2002, hlm. 27.

${ }^{12}$ Sudargo Gautama dan Rizawanto Winata, Hukum Merek Indonesia, Citra Aditya Bakti, Bandung, 1993, hlm. 40.

${ }^{13}$ M. Yahya Harahap, Tinjauan Merek Secara Umum dan Hukum Merek di Indonesia Berdasarkan Undang-Undang Nomor 19 Tahun 1992, Citra Aditya Bakti, Bandung, 1996, hlm. 80. 
berperan meramaikan persaingan usaha di pasaran. Jangkauan pemasarannya sangat sempit dan terbatas pada lokal, sehingga merek jenis ini tidak dianggap sebagai saingan utama, serta tidak pula menjadi incaran para pedagang atau pengusaha untuk ditiru atau dipalsukan.

2. Merek Terkenal, merek terkenal biasa disebut juga sebagai "well known mark". Merek jenis ini memiliki reputasi tinggi karena lambangnya memiliki kekuatan untuk menarik perhatian. Contohnya, adalah produk Honda, baik sepeda motor maupun mobil, bahkan sampe ada di suatu daerah yang menyebutkan Honda untuk semua merek sepeda motor. Sehingga merek Honda dapat dikategorikan sebagai merek terkenal (well known mark) karena pengetahuan masyarakat mengenai merek ini baik di dalam maupun di luar negeri.

3. Merek Termasyhur, sedemikian rupa terkenalnya suatu merek sehingga dikategorikan sebagai "famous mark". Derajat merek termasyhur pun lebih tinggi daripada merek biasa, sehingga jenis barang apa saja yang berada di bawah merek ini langsung menimbulkan sentuhan keakraban dan ikatan mitos. ${ }^{14}$ Contoh yang dapat diambil untuk jenis merek termasyhur adalah jenis kendaraan mobil TOYOTA, yang sangat terkenal dan diakui kemewahannya

Fungsi merek adalah sebagai pembeda antara satu produk barang atau jasa dengan produk barang atau jasa yang dibuat oleh pihak lain. ${ }^{15}$ Direktorat Jenderal Hak Kekayaan Intelektual memaparkan fungsi merek sebagai berikut:

a. Sebagai tanda pengenal untuk membedakan produk perusahaan yang satu dengan yang lain (product identity). Fungsi ini juga menghubungkan barang atau jasa dengan produsennya sebagai

\footnotetext{
${ }^{14}$ Budi Agus Riswandi dan M. Syamsuddin, Hak Kekayaan intelektual dan Budaya Hukum, Raja Grafindo Persada, Jakarta, 2004, hlm. 87.

${ }^{15}$ Racmadi Usman, Op.Cit. hal. 322.
} 
jaminan reputasi hasil usahanya ketika diperdagangkan.

b. Sebagai sarana promosi untuk berdagang (means of trade promotion). Promosi dilakukan melalui iklan. Merek merupakan salah satu goodwill untuk menarik konsumen, merupakan simbol pengusaha untuk memperluas pasar produk atau barang dagangannya.

c. Sebagai jaminan atas mutu barang atau jasa (quality guarantee). Hal ini menguntungkan pemilik merek dan juga memberikan perlindungan jaminan mutu barang atau jasa bagi konsumen.

d. Sebagai penunjukan asal barang atau jasa yang dihasilkan (source of origin). Merek merupakan tanda pengenal asal barang atau jasa yang menghubungkannya dengan produsen atau daerah/negara asalnya. ${ }^{16}$

Sistem pendaftaran deklaratif adalah suatu sistem dimana yang memperoleh perlindungan hukum adalah pemakai pertama dari merek yang bersangkutan. Sistem pendaftaran deklaratif ini dianut dalam Undang-Undang Nomor: 21 Tahun 1961. Dengan perkataan lain, bukan pendaftaran yang menciptakan suatu hak atas merek, tetapi sebaliknya pemakaian pertama di Indonesialah yang menciptakan atau menimbulkan hak itu. ${ }^{17}$ Sistem pendaftaran deklaratif pada Undang-Undang No 21 Tahun 1961 dapat diketahui dari ketentuan Pasal 2 yang berbunyi:

“(1) Hak khusus untuk memakai suatu merek guna memperbedakan barang-barang hasil perusahaan atau barang-barang perniagaan seseorang atau suatu badan dari barang-barang orang lain atau badan lain kepada barang siapa yang untuk pertama kali memakai merek itu untuk keperluan tersebut diatas di Indonesia“.

Dalam pendaftaran merek yang sistem deklaratif, pendaftaran itu sendiri bukan merupakan suatu keharusan. Artinya pemilik merek yang memakai pertama tetap dapat memperoleh perlindungan hukum, meskipun tidak

\footnotetext{
${ }^{16}$ Direktorat Jenderal HKI, Buku Panduan Hak Kekayaan Intelektual (Pertanyaan \& Jawabannya).: Ditjen HKI Depkeh \& HAM, Jakarta, 2000, hlm. 42.

${ }^{17}$ Sudargo Gautama dan Rizawanto, op.cit. Hal. 20. 
didaftarkan. ${ }^{18}$ Untuk membuktikan sebagai pemakai pertama kali suatu merek dapat dengan menunjukkan faktur-faktur atau konosemen yang dikirim oleh pabrik kepada pedagang yang mencantumkan merek barang yang diperdagangkan, iklan-iklan pada surat kabar atau televisi dan pemakaian merek pada pameran. ${ }^{19}$

Pendaftaran dalam sistem deklaratif lebih berfungsi untuk memudahkan pembuktian, artinya dengan adanya surat memperoleh surat pendaftaran maka akan mudah untuk membuktikan apabila ada pihak lain yang mengaku sebagai pemilik merek yang bersangkutan tentu saja hal ini berlaku sepanjang pihak lain tidak dapat membuktikan sebagai pemakai pertama kali merek yang didaftarkan tersebut. Jadi pendaftar pertama kali atas suatu merek hanya sebagai dugaan hukum sebagai pemakai pertama kali.

Pendaftaran merek dengan sistem deklaratif ini mengandung ketidakpastian hukum, sebab pendaftaran suatu merek sewaktu-waktu dapat dibatalkan apabila ada pihak lain yang dapat membuktikan sebagai pemilik pertama dari merek yang telah didaftarkan. Oleh karena itulah, pendaftaran dengan sistem deklaratif di Indonesia telah tidak lagi digunakan sejak berlakunya Undang-Undang Nomor: 19 Tahun 1992 tentang Merek.

Dalam pendaftaran merek dengan sistem konstitutif, Pendaftaran Merek merupakan keharusan agar dapat memperoleh hak atas merek. Tanpa pendaftaran, negara tidak akan memberikan hak atas merek kepada pemilik merek. Hal ini berarti tanpa mendaftarkan merek, seseorang tidak akan diberikan perlindungan hukum oleh negara apabila mereknya ditiru oleh orang lain. Pendaftaran merek yang digunakan di Indonesia sejak Undang-Undang Nomor 19 Tahun 1992 adalah sistem Konstitutif. Pada sistem konstitutif ini perlindungan hukumnya didasarkan atas pendaftar pertama yang beritikad baik. Hal ini juga seperti yang tercantum dalam Pasal 4 Undang-Undang Nomor 20 Tahun 2016 yang menyatakan bahwa merek tidak dapat didaftar oleh pemohon yang tidak

\footnotetext{
18 Ibid, hlm. 33.

${ }^{19}$ Ibid, hlm. 30.
} 
beritikad baik.

Permohonan merek harus ditolak apabila merek tersebut mempunyai persamaan pada pokoknya atau keseluruhannya dengan merek pihak lain yang sudah terdaftar terlebih dahulu untuk barang atau jasa yang sejenis, mempunyai persamaan pada pokoknya atau keseluruhannya dengan indikasi geografis yang sudah dikenal. ${ }^{20}$ Berdasarkan ketentuan persyaratan merek agar dapat didaftarkan, sesuatu dapat dikategorikan dan diakui sebagai merek, apabila: mempunyai fungsi pembeda; merupakan tanda pada barang atau jasa (unsurunsur gambar, nama, kata, huruf, angka, susunan warna atau kombinasi dari unsur-unsur tersebut); tidak memenuhi unsur-unsur yang bertentangan dengan kesusilaan dan ketertiban umum; bukan menjadi milik umum; dan tidak merupakan keterangan, atau berkaitan dengan barang atau jasa yang dimintakan pendaftaran.

Selain pemeriksaan substantif, harus pula ditempuh mekanisme Pengumuman dalam waktu paling lama 15 hari dengan menempatkan pada papan pengumuman yang khusus dan dapat dengan mudah dilihat oleh masyarakat dalam Berita Resmi Merek yang diterbitkan secara berkala oleh Direktorat Jenderal Kekayaan Intelektual. Hal ini dilakukan untuk memungkinkan pihakpihak yang dirugikan mengajukan bantahan terhadap pendaftaran merek dan dapat mencegah pendaftaran merek yang dilakukan oleh orang yang tidak beritikad baik.

Komisi Banding Merek merupakan badan khusus yang independen yang berada di lingkungan Direktorat Hak Kekayaan Intelektual. Keputusan yang diberikan oleh Komisi Banding Merek paling lama 3 (tiga) bulan terhitung sejak tanggal penerimaan permohonan banding. Keputusan Komisi Banding bersifat final dan mengikat. Apabila komisi banding merek mengabulkan permintaan banding, Direktorat Merek melaksanakan pendaftaran dan memberikan sertifikat merek. Jika ditolak, pemohon dan kuasanya dapat mengajukan gugatan atas putusan penolakan permohonan banding kepada Pengadilan Niaga dalam waktu

${ }^{20}$ Ahmadi M. Ramli, Cyber Law dan HAKI dalam Sistem Hukum Indonesia, Refika Aditama Bandung, 2004, hlm. 11. 
paling lambat 3 (tiga) bulan terhitung sejak tanggal diterimanya keputusan penolakan. $^{21}$

Berdasarkan Pasal 1 (6), UU No. 20 Tahun 2016 Tentang Merek dan Indikasi Geografis, definisi Indikasi Geografis, yaitu:

Indikasi Geografis adalah suatu tanda yang menunjukkan daerah asal suatu barang dan/atau produk yang karena faktor lingkungan geografis termasuk faktor alam, faktor manusia atau kombinasi dari kedua faktor tersebut memberikan reputasi, kualitas, dan karakteristik tertentu pada barang dan/atau produk yang dihasilkan

Indikasi geografis berbeda dengan aspek HKI lainnya seperti paten, merek, hak cipta dan disain industri dimana indikasi geografis sebagai pemohon adalah lembaga- lembaga yang mewakili masyarakat di daerah yang memproduksi barang, lembaga pemerintah daerah yang di beri wewenang baik tingkat provinsi maupun kabupaten. Untuk memahami hubungan antara hak kekayaan intelektual dan indikasi geografis dapat ditelusuri dari pemahaman terhadap indikasi geografis sendiri. Indikasi geografis dapat diartikan sebagai: ${ }^{22}$

A geographical indication is a sign used on goods that have a specific geographical origin and possess qualities or a reputation that are due to that place of origin. Most commonly, a geographical indication consists of the name of the place of origin of the goods. Agricultural products typically have qualities that derive from their place of production and are influenced by specific local factors, such as climate and soil. Whether a sign functions as a geographical indication is a matter of national law and consumer perception.

Berdasarkan pengertian di atas, dapat diambil suatu batasan bahwa sesungguhnya indikasi geografis adalah suatu tanda ( $a$ sign) pada barang yang mempunyai asal geografis yang spesifik dan mempunyai kualitas atau suatu reputasi yang teruji dari asal tempatnya. Secara garis besar, suatu indikasi

${ }^{21}$ Erna Wahyuni, dkk, Kebijakan dan Manajemen Hukum Merek, YPAPI, Yogyakarta, 2004, hlm. 96.

22 "Geographical Indications" http://www.wipo.int/aboutip/en/geographical_ind.html, diakses tanggal 8 Juni 2017. 
geografis meliputi nama asal tempat dan asal barang. Secara tipikal, produkproduk pertanian mempunyai kualitas yang mengarah dari produksi tempat mereka dan dipengaruhi secara spesifik oleh faktor lokal, seperti iklim dan tanah. Apapun suatu tanda berfungsi sebagai suatu indikasi geografis merupakan suatu materi hukum nasional dan persepsi konsumen.

WTO memberikan batasan indikasi geografis adalah place names (in some countries also words associated with a place) used to identify the origin and quality, reputation or other characteristics of products (for example, "Champagne”, "Tequila” or "Roquefort”). ${ }^{23}$ Nama-nama tempat (di beberapa negara juga katakata yang diasosiasikan dengan suatu tempat) digunakan untuk mengidentifikasi asal dan kualitas, reputasi atau karakteristik lainnya dari suatu produk, untuk contoh; "Champagne”, "Tequila” atau "Roquefort")

Perlindungan indikasi geografis dapat menyebabkan nilai produk menjadi lebih tinggi, sehingga indikasi geografis dapat menggerakkan perekonomian suatu daerah asal produk indikasi geografis dan indikasi geografis ditujukan pada produsennya bukan pada petaninya. Konsep indikasi geografis adalah perlindungan komunal, oleh karena itu dalam proses perlindungan indikasi geografis pelaksanaannya dapat dilakukan dengan memberdayakan dari kalangan LSM, dari dinas-dinas pemerintah, warga sekitar untuk membuat uraian/deskripsi atas produknya yang didaftarkan sebagai indikasi geografis. Jumlah indikasi geografis di Indonesia masih banyak hanya saja tidak dimonitoring. Indikasi geografis baru dilindungi dan mendapat perlindungan setelah didaftarkan sebagaimana HAKI kita menganut prinsip first to file.

Peran Ditjen HKI khususnya Subdit Indikasi geografis dalam melindungi produk-produk yang termasuk dalam indikasi geografis yaitu:

1. Sosialisasi tentang indikasi geografis ke daerah-daerah yang memiliki produk indikasi geografis;

2. Menginfentarisasi produk-produk yang mempunyai nilai indikasi geografis bekerja sama dengan Kanwil Kementerian Hukum dan

23 "Geographical Indications" http://www.wto.org/english/tratop_e/trips_e/gi_e.htm, diakses tanggal 8 Juni 2017. 
HAM serta instansi terkait;

3. Pengadministrasian permohonan pendaftaran indikasi geografis.

\section{b. Bentuk Pelanggaran Hukum Atas Merek Dagang Terkenal dari Tindakan Passing Off}

Pada era perdagangan bebas, hak merek merupakan faktor penting dalam menciptakan sistem perdagangan yang fair. Merek adalah tanda pengenal asal barang atau jasa yang bersangkutan dengan produsennya yang menggambarkan jaminan kepribadian (individuality) dan reputasi barang atau jasa pada waktu diperdagangkan. Dalam kehidupan perdagangan selalu ada tindakan yang mencoba meraih keuntungan melalui jalan pintas dengan segala cara tindakan tersebut melanggar etika bisnis, norma kesusilaan, bahkan melanggar hukum. ${ }^{24}$ Bentuk pelanggaran merek seperti penggunaan merek yang sama pada keseluruhannya atau pada pokoknya dengan merek terdaftar milik pihak lain, melainkan peniruan, pemalsuan yang dipakai pada barang atau jasa yang diperdagangkan. ${ }^{25}$

Dalam kepustakaan Indonesia sendiri, sebelumnya tindakan passing off belum dikenal secara luas terkait definisinya dan secara detail uraian bentuk tindakannya, akan tetapi hanya menyimpulkan bahwa passing off merupakan tindakan pemboncengan pada suatu merek terkenal. Namun, pada negara-negara anglo-american law (common law system) seperti Inggris, Australia, Malaysia, Amerika Serikat atau lebih lanjut yakni negara-negara bekas jajahan atau persemakmuran kerajaan Inggris sudah lebih dulu mengenal dan mengatur apa yang dimaksud dengan passing off sebagai suatu bentuk tindakan persaingan curang (unfair competition) dalam bidang usaha perdagangan atau perniagaan. Seperti contohnya di Australia saja, tindakan passing off tidak diatur di peraturan HKI mereka akan tetapi diatur dalam regulasi peraturan perundang-undangan

${ }^{24}$ Sonny Keraf, Etika Bisnis-Membangun Citra Bisnis Sebagai Profesi Luhur, Kanisius, Yogyakarta, 1998, hlm. 69.

25 Imas Rosidawati Wiradirja, Juli Asril. Model Perlindungan Hak Kekayaan Intelektual Atas Pemalsuan dan Peniruan Merek Melalui Pengawasan Perbatasan Oleh Bea Cukai Dalam Era Perdagangan Bebas. E-Journal Kopertis 4. 
perdagangan sebagai suatu tindakan curang dalam perdagangan pada Pasal 52 Undang- Undang Praktek Perdagangan Australia 1974 yang menyatakan bahwa:

"Suatu perusahaan dalam perdagangan dan perniagaan tidak diperkenankan terlibat dalam tindak tipu muslihat dan kecurangan atau kecenderungan menyesatkan atau mencurangi”

Selanjutnya telah dijelaskan sebelumnya yakni passing off merupakan tindakan pendomplengan terhadap merek terkenal yang dapat merugikan pemegang merek. ${ }^{26}$ Passing off dapat dikatakan sebagai tindakan yang mencoba meraih keuntungan melalui jalan pintas dengan segala macam cara dan dalih dengan melanggar etika bisnis, norma kesusilaan, maupun hukum. ${ }^{27}$ Tindakan tersebut pelaku usaha tidak jujur yang seringkali terjadi dalam praktik perdagangan. Dari tindakan tersebutlah seharusnya upaya pencegahan dan perlindungan atas merek dagang terkenal dari tindakan pemboncengan atas merek dagang terkenal yang biasa disebut dengan tindakan passing off oleh karena itu penegakan hukum merek harus mendapatkan perhatian serius.

Sikap menarik langganan atau menarik klien dengan cara curang biasanya banyak dilakukan oleh seorang pengusaha atau badan usaha dalam memajukan usaha perdagangannya sendiri dan memperluas pasar dengan cara meningkatkan kapasitas penjualannya atas suatu barang atau jasa. Akan tetapi hal itu dilakukan dengan cara yang tidak jujur dan tidak menggunakan iktikad baik dalam menaati dan menjalankan norma-norma tidak tertulis maupun tertulis dalam pergaulan ekonomi.

Melihat suksesnya dan tingginya reputasi suatu merek dagang oleh suatu badan usaha dengan produknya di kalangan masyarakat selaku konsumen atas produk tersebut membuat banyak pihak memanfaatkan situasi tersebut untuk ikut mendapatkan keuntungan pada keterkenalan suatu merek dari penciptanya. Alhasil, hal tersebut membuat banyak pihak menyiasati keuntungan tersebut dengan banyak cara yang kemudian menabrak norma kesusilaan dan norma

${ }^{26}$ Mieke Yustia Ayu Ratna Sari, Passing Off Dalam Pendaftaran Merek, Kajian Putusan Mahkamah Agung Nomor 224 K/Pdt.Sus-HKI/2014. Jurnal Yudisial Vol. 7 No. 3 Desember 2014, hlm. 256.

${ }^{27}$ Ibid, hlm. 263 
hukum dalam etika bisnis. Ketergodaan dari banyak pihak kemudian kemudian menjadi pesaing usaha melalui cara diantaranya dengan membonceng, meniru dengan mengikuti dan memirip-miripkan baik bentuk dan ciri-ciri atas produk barang atau jasa suatu karya dari merek yang telah memiliki reputasi yang tinggi.

Adanya pihak yang berbuat demikian dalam kaitannya persaingan usaha menjadi pihak lain yang dibenceng, ditiru dengan kemiripan dan dimiripmiripkan baik bentuk dan ciri-cirinya barang atau jasa membuat pihak selaku pencipta merek dagang mengalami kerugian yang berupa menurunnya omzet penjualan atas barang atau jasa dari pelanggannya. Sehingga hal tersebut membuat terkecohnya pelanggan yang sebelumnya telah berlangganan memilih barang atau jasa dari produsen yang memiliki merek terkenal kepada merek lain yang membonceng dari merek terkenal tersebut, di satu sisi yang lebih memprihatinkan lagi hal tersebut mendapatkan suatu klaim sepihak atas produk atau jasa dari pihak lain yang mendompleng merek dagang terkenal tersebut, dari tindakan tersebutlah itikad tidak baik timbul dari suatu pelanggaran atas hak merek pada persaingan usaha tidak sehat.

Pada Prinsipnya suatu tindakan dapat dikategorikan passing off, apabila memenuhi tiga elemen. ${ }^{28}$ Elemen pertama adanya reputasi yang terdapat pada pelaku usaha yaitu apabila seorang pelaku usaha memiliki reputasi bisnis yang baik di mata publik dan usahanya tersebut cukup dikenal oleh umum. Keadaan demikian dimanfaatkan oleh pesaing pelaku usaha. Elemen kedua, adanya misrepresentasi dalam hal ini terkenalnya merek yang dimiliki oleh pelaku usaha, apabila ada pelaku usaha lain mendompleng merek yang sama maka publik mudah terkecoh (misleading) atau terjadi kebingungan (confusion) dalam memilih produk yang diinginkan. Elemen ketiga, terdapat kerugian yang timbul akibat tindakan pendomplengan atau pemboncengan yang dilakukan oleh pengusaha dengan iktikad tidak baik menggunakan merek yang mirip atau serupa dengan merek yang telah dikenal sehingga terjadi kekeliruan memilih produk oleh publik (publik misleading).

${ }^{28} \mathrm{Ibid}, \mathrm{hlm} 263$. 
Dalam mengakomodir tindakan passing off di Indonesia, untuk memberikan perlindungan pemegang hak merek terkenal di Indonesia seharusnya dapat diatur di dalam undang-undang larangan monopoli dan persaingan usaha tidak sehat atau hukum anti monopoli ataupun lebih khususnya pada undang-undang tentang merek oleh pemerintah Indonesia. Akan tetapi dalam undang-undang larangan monopoli dan persaingan usaha tidak sehat atau hukum anti monopoli pengaturan melalui Undang- Undang Nomor 5 Tahun 1999 Tentang Larangan Monopoli dan Persaingan Usaha Tidak Sehat kepengaturan tentang passing off tidak muncul dan diatur secara rigid.

Muatan isi yang tertuang dalam Undang-Undang Nomor 5 Tahun 1999 Tentang Larangan Monopoli dan Persaingan Usaha Tidak Sehat secara jelas dan detail hanya mengatur tentang dalam usaha pencegahan tindakan monopoli perdagangan dan praktek-praktek komersial yang menghambat dan mencegah persaingan dalam pasar. Hal itu tersirat pokok pikiran bahwa adanya peraturan anti monopoli ditujukan hanya untuk memastikan bahwa adanya klausul yang memadai pada persaingan usaha di pasar secara terbuka ataupun tertutup atas barang atau jasa dan mencegah suatu badan usaha menjadi begitu kuat melalui praktek monopoli, monopsoni, penguasaan pasar dan persekongkolan. Oleh karena itu, dalam Undang-Undang Nomor 5 Tahun 1999 Tentang Larangan Monopoli dan Persaingan Usaha Tidak Sehat tidak diatur perbuatan mengenai passing off sebagai suatu bentuk persaingan usaha tidak sehat.

Selanjutnya, membahas muatan isi dalam Undang-Undang Nomor 20 Tahun 2016 Tentang Merek dan Indikasi Geografis, konten isi dalam peraturan merek tersebut sudah mengalami pergeseran dan pengakomodiran lanjutan dari ketentuan peraturan merek yang sebelumnya diatur dalam Undang-Undang Nomor 15 Tahun 2001 Tentang Merek. Pergeseran tersebut merupakan suatu amandemen ulang dalam mengakomodir perkembangan dalam hukum merek secara internasional karena Indonesia tergabung dalam World Trade Organization (WTO). Perubahan tersebut meliputi: (a) perubahan judul, (b) perluasan tipe merek, (c) perubahan alur dalam proses pendaftaran merek, (d) jangka waktu proses pendaftaran merek sampai diberikan sertifikat atas hak 
merek, (e) perpanjangan pendaftaran merek, (f) pendaftaran merek internasional, (g) pengaturan tentang indikasi geografis, (h) pengaturan mengenai ketentuan pidana.

Terkait tindakan pemboncengan atas merek terkenal (passing off) merupakan tindakan illegal dalam persaingan usaha dan apabila merek yang membonceng tersebut didaftarkan kepada Ditjen HKI Republik Indonesia pun akan ditolak karena dianggap sebagai merek yang memiliki persamaan pada pokoknya. Secara lanjut dasar ditolaknya permohonan atas pendaftaran merek yang memiliki pola persamaan pada pokoknya diatur dalam ketentuan Pasal 21 ayat 1 Undang-Undang Nomor 20 Tahun 2016 Tentang Merek dan Indikasi Geografis, apalagi hal tersebut dilandasi pada perbuatan yang mengandung iktikad tidak baik menurut ketentuan pasal 21 ayat 3.

Ketentuan Pasal 21 ayat 1, menyebutkan permohonan ditolak jika merek tersebut mempunyai persamaan pada pokoknya atau keseluruhannya dengan: merek terdaftar milik pihak lain atau dimohonkan lebih dahulu oleh pihak lain untuk barang dan/atau jasa sejenis, merek terkenal milik pihak lain untuk barang dan/atau jasa sejenis, merek terkenal milik pihak lain untuk barang dan/atau jasa tidak sejenis yang memenuhi persyaratan tertentu, atau Indikasi Geografis terdaftar. Sementara ketentuan Pasal 21 ayat 3 menyebutkan permohonan ditolak jika diajukan oleh pemohon yang beriktikad tidak baik.

Ketentuan dari kedua ayat tersebut sejatinya tersirat makna yang hampir sama dengan tindakan passing off atas sebuah merek oleh seorang pengusaha atau badan usaha. Tindakan passing off sendiri merupakan tindakan yang membonceng merek terkenal, hal tersebut dilandasi karena merek terkenal sudah diketahui dan menjadi umum di masyarakat atas suatu barang atau jasa. Untuk itu tindakan pemboncengan tersebut dapat dianalogikan sebagai klausul persamaan pada pokoknya. Selain itu, hal tersebut juga sudah diatur dalam Undang-Undang Merek Nomor 15 Tahun 2001 akan tetapi Undang-Undang Nomor 20 Tahun 2016 Tentang Merek dan Indikasi Geografis mengatur kembali 
dengan lebih detail dan jelas.

Sengketa gugatan tentang tindakan passing off sebelumnya sudah pernah ada di Indonesia dengan digugatnya produk Aki dengan merek dagang "GiSi" buatan PT Gramitrama Battery Indonesia (PT GBI) oleh PT GS Yuasa Corporation dengan merek dagang "GS”. Gugatan tersebut dimenangkan oleh PT GS Yuasa Corporation pada tahun 2012 oleh Pengadilan Niaga pada Pengadilan Negeri Jakarta Pusat. Hakim mengabulkan gugatan PT GS Yuasa Corporation dengan putusan No. 83/Merek/2012/PN.Niaga.Jkt.Pst tanggal 3 April 2013 dan dikuatkan oleh putusan Mahkamah Agung Republik Indonesia No. 130 PK/Pdt.Sus-HKI/2014 tanggal 21 Januari 2015.

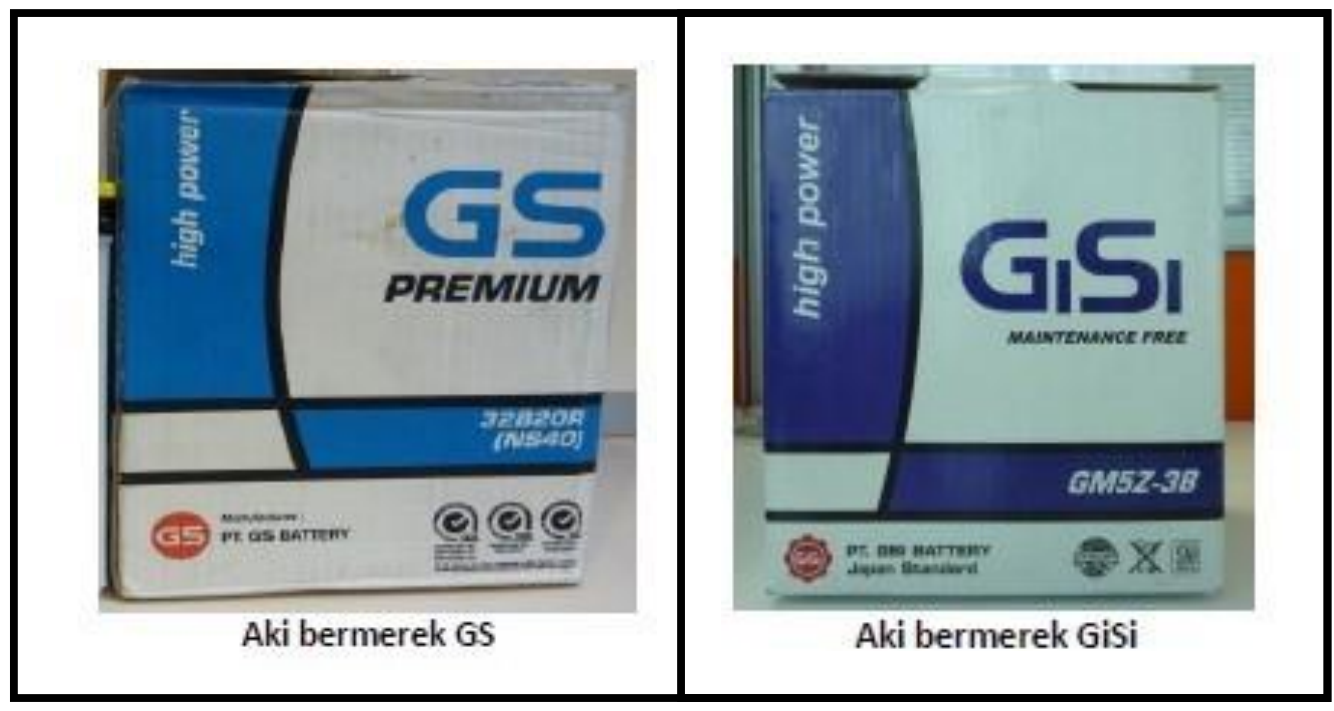

Setelah amandemen Undang-Undang Nomor 15 Tahun 2001 Tentang Merek dengan Undang-Undang Nomor 20 Tahun 2016 Tentang Merek dan Indikasi Geografis tetap mendapatkan perluasan kepengaturan seperti yang telah dijelaskan diatas, akan tetapi fungsi preventif dan fungsi represif dari UndangUndang Merek tetap ada dan mendapatkan penguatan di Undang-Undang terbaru tahun 2016. Fungsi preventif

Setelah amandemen Undang-Undang Nomor 15 Tahun 2001 Tentang Merek dengan Undang-Undang Nomor 20 Tahun 2016 Tentang Merek dan Indikasi Geografis tetap mendapatkan perluasan kepengaturan seperti yang telah dijelaskan diatas, akan tetapi fungsi preventif dan fungsi represif dari Undang- 
Undang Merek tetap ada dan mendapatkan penguatan di Undang-Undang terbaru tahun 2016. Fungsi preventif

Hakim menilai perbuatan dari PT Gramitrama Battery Indonesia (PT GBI) atas produknya Aki dengan merek dagang "GiSi" merupakan tindakan yang dinilai menurut keyakinan hakim sebagai upaya jalan pintas (free riding) dengan membonceng keterkenalan (passing off) merek pihak PT GS Yuasa Corporation untuk mengambil keuntungan sebanyak-banyaknya secara tidak patut menurut norma hukum dan perbuatan tersebut juga dinilai merupakan tindakan yang tidak memiliki itikad baik atas produknya yang membonceng kemasyhuran dari PT GS Yuasa Corporation. Walaupun kasus tersebut diproses pada Pengadilan Niaga dengan menggunakan acuan Undang- Undang Nomor 15 Tahun 2001 Tentang Merek, tidak membuat hakim kesulitan dalam membuat kerangka pertimbangan dalam memberikan putusan dalam sengketa passing off tersebut yang bergulir 2012 hingga 2015.

Setelah amandemen Undang-Undang Nomor 15 Tahun 2001 Tentang Merek dengan Undang-Undang Nomor 20 Tahun 2016 Tentang Merek dan Indikasi Geografis tetap mendapatkan perluasan kepengaturan seperti yang telah dijelaskan diatas, akan tetapi fungsi preventif dan fungsi represif dari UndangUndang Merek tetap ada dan mendapatkan penguatan di Undang-Undang terbaru tahun 2016. Fungsi preventif berupa penolakan pendaftaran dari otoritas yang berwenang yakni Ditjen HKI atas pendaftaran suatu merek yang memiliki persamaan pada pokoknya dan berdasarkan iktikad tidak baik sebagaimana yang telah diatur dalam Pasal 21 Undang-Undang Nomor 20 Tahun 2016 Tentang Merek dan Indikasi Geografis, dan fungsi represif terdapat dalam Pasal 66, Pasal 67, Pasal 68, dan Pasal 69 Undang-Undang Nomor 20 Tahun 2016 Tentang Merek dan Indikasi Geografis.

Adapun ketentuan Pasal 66 menyebutkan bahwa pelanggaran atas Indikasi Geografis mencakup:

(1) pemakaian Indikasi Geografis, baik secara langsung maupun tidak langsung atas barang dan/atau produk yang tidak memenuhi Dokumen 
Deskripsi Indikasi Geografis;

(2) pemakaian suatu tanda Indikasi Geografis, baik secara langsung maupun tidak langsung atas barang dan/atau produk yang dilindungi atau tidak dilindungi dengan maksud untuk:

a. menunjukkan bahwa barang dan/atau produk tersebut sebanding kualitasnya dengan barang dan/atau produk yang dilindungi oleh Indikasi Geografis;

b. mendapatkan keuntungan dari pemakaian tersebut; atau

c. mendapatkan keuntungan atas reputasi Indikasi Geografis.

(3) pemakaian Indikasi Geografis yang dapat menyesatkan masyarakat sehubungan dengan asal-usul geografis barang itu;

(4) pemakaian Indikasi Geografis oleh bukan Pemakai Indikasi Geografis terdaftar;

(5) peniruan atau penyalahgunaan yang dapat menyesatkan sehubungan dengan asal tempat barang dan/atau produk atau kualitas barangdan/atau produk yang terdapat pada:

a. pembungkus atau kemasan;

b. keterangan dalam iklan;

c. keterangan dalam dokumen mengenai barang dan/atau produk tersebut; atau

d. informasi yang dapat menyesatkan mengenai asal-usulnya dalam suatu kemasan.

(6) tindakan lainnya yang dapat menyesatkan masyarakat luas mengenai kebenaran asal barang dan/atau produk tersebut.

Sementara ketentuan Pasal 67 menyebutkan bahwa terhadap pelanggaran sebagaimana dimaksud dalam Pasal 66 dapat diajukan gugatan. Gugatan tersebut dapat dilakukan oleh: setiap produsen yang berhak menggunakan Indikasi Geografis; dan/atau lembaga yang mewakili masyarakat di kawasan geografis tertentu dan yang diberi kewenangan untuk itu. Dalam hal sebelum atau pada saat dimohonkan pendaftaran sebagai Indikasi Geografis, suatu tanda dipakai dengan iktikad baik oleh pihak lain yang tidak berhak mendaftar menurut ketentuan Pasal 
53 ayat (3), pihak yang beriktikad baik tersebut tetap dapat menggunakan tanda tersebut untuk jangka waktu 2 (dua) tahun terhitung sejak tanda tersebut terdaftar sebagai Indikasi Geografis.

Dalam hal tanda tersebut telah terdaftar sebagai Merek, Menteri membatalkan dan mencoret pendaftaran Merek tersebut untuk seluruh atau sebagian jenis barang yang sama setelah jangka waktu 2 (dua) tahun terhitung sejak tanda tersebut terdaftar sebagai Indikasi Geografis. Pembatalan dan pencoretan pendaftaran Merek diberitahukan secara tertulis kepada pemilik Merek atau Kuasanya dengan menyebutkan alasannya. Pembatalan dan pencoretan pendaftaran Merek dicatat dan diumumkan dalam Berita Resmi Merek.

Pembatalan dan pencoretan pendaftaran Merek mengakibatkan berakhirnya pelindungan hukum atas Merek tersebut untuk seluruh atau sebagian jenis barang yang sama. Keberatan terhadap pembatalan dan pencoretan dapat diajukan kepada Pengadilan Niaga. Terhadap putusan Pengadilan Niaga dapat diajukan kasasi. ${ }^{29}$

Pemegang Hak atas Indikasi Geografis dapat mengajukan gugatan terhadap Pemakai Indikasi Geografis yang tanpa hak berupa permohonan ganti rugi dan penghentian penggunaan serta pemusnahan label Indikasi Geografis yang digunakan secara tanpa hak. Untuk mencegah kerugian yang lebih besar pada pihak yang haknya dilanggar, hakim dapat memerintahkan pelanggar untuk menghentikan kegiatan pembuatan, perbanyakan, serta memerintahkan pemusnahan label Indikasi Geografis yang digunakan secara tanpa hak. ${ }^{30}$

Bertitik belakang pada ketentuan Undang-Undang Nomor 20 Tahun 2016 Tentang Merek dan Indikasi Geografis sebagai dasar regulasi perlindungan merek terkenal (well-known or famous mark) terhadap tindakan passing off, setidaknya memuat 3 ketentuan sebagai dasar pijakan kerangka pikiran. Diantara dasar pijakan kerangka pikiran tersebut yakni, pertama adanya unsur persamaan

\footnotetext{
${ }^{29}$ Pasal 68 Undang-Undang Nomor 20 Tahun 2016 Tentang Merek dan Indikasi Geografis ${ }^{30}$ Pasal 69, Undang-Undang Nomor 20 Tahun 2016 Tentang Merek dan Indikasi Geografis.
} 
pada pokoknya maupun keseluruhannya sehingga menimbulkan penyesatan pada masyarakat tentang asal barang, kedua, merek yang ditiru adalah merek terkenal yang telah mempunyai reputasi dan, ketiga adalah peniruan tersebut menimbulkan kerugian pada pemilik merek sesungguhnya ${ }^{31}$ dan dilandasi dengan iktikad tidak baik dari pelaku usaha dalam kaitannya pada aktivitas bisnis.

\section{PENUTUP}

Passing off merupakan tindakan pendomplengan terhadap merek terkenal yang dapat merugikan pemegang merek. Passing off dapat dikatakan sebagai tindakan yang mencoba meraih keuntungan melalui jalan pintas dengan segala macam cara dan dalih dengan melanggar etika bisnis, norma kesusilaan, maupun hukum. Tindakan tersebut pelaku usaha tidak jujur yang seringkali terjadi dalam praktik perdagangan kaitannya pelanggaran Hak Kekayaan Intelektual. Perlindungan hukum merek dagang terkenal atas tindakan passing off saat ini belum memadai karena dalam undang-undang larangan monopoli dan persaingan usaha tidak sehat atau hukum anti monopoli pengaturan melalui Undang-Undang Nomor 5 Tahun 1999 Tentang Larangan Monopoli dan Persaingan Usaha Tidak Sehat tindakan passing off tidak diatur secara rigid.

Bentuk pelanggaran merek dagang terkenal melalui tindakan passing of apabila memenuhi 3 (tiga) kriteria. Pertama, adanya reputasi yang terdapat pada pelaku usaha yaitu apabila seorang pelaku usaha memiliki reputasi bisnis yang baik di mata publik dan usahanya tersebut cukup dikenal oleh umum. Keadaan demikian dimanfaatkan oleh pesaing pelaku usaha. Kedua, adanya misrepresentasi dalam hal ini terkenalnya merek yang dimiliki oleh pelaku usaha, apabila ada pelaku usaha lain mendompleng merek yang sama maka publik mudah terkecoh (misleading) atau terjadi kebingungan (confusion) dalam memilih produk yang diinginkan. Ketiga, terdapat kerugian yang timbul akibat tindakan pendomplengan atau pemboncengan yang dilakukan oleh pengusaha dengan iktikad tidak baik menggunakan merek yang mirip atau serupa dengan

${ }^{31}$ Rifky Ardian, dkk, Loc,cit, hm. 14. 
merek yang telah dikenal sehingga terjadi kekeliruan memilih produk oleh publik. (publik misleading).

Untuk memberikan perlindungan hukum atas merek dagang terkenal dari tindakan passing off di Indonesia, sebaiknya pemerintah mengatur tindakan passing off dalam undang-undang larangan monopoli dan persaingan usaha tidak sehat atau hukum anti monopoli dan undang-undang tentang merek, sehingga penegak hukum memiliki dasar hukum yang kuat untuk melakukan tindakan hukum bagi pelaku yang melakukan tindakan passing off.

Untuk meminimalisasi berbagai bentuk pelanggaran terhadap merek dagang terkenal sebaiknya pemerintah melakukan pengawasan terhadap pemanfaatan merek terkenal, supaya tidak merugikan pemilik merek dan tidak mengurangi potensi tindakan yang mengelabui konsumen merek terkenal. 


\section{DAFTAR ISI}

\section{A. Buku}

Ahmadi M. Ramli. Cyber Law dan HAKI dalam Sistem Hukum Indonesia, Refika Aditama, Bandung, 2004.

Ahmad M. Ramli. Hak atas Kepemilikan Intelektual: Teori Dasar Perlindungan Rahasia Dagang, Mandar Maju, Bandung, 2000.

Budi Agus Riswandi dan M. Syamsuddin. Hak Kekayaan intelektual dan Budaya Hukum, Raja Grafindo Persada, Jakarta, 2004.

Eddy Damian, Dkk. Hak Kekayaan Intelektual (Suatu Pengantar), Alumni, Bandung, 2003.

Erna Wahyuni, T. Saiful Bahri, Hassel Nogi S. Tangkilisan. Kebijakan dan Manajemen Hukum Merek, YPAPI, Yogyakarta, 2004.

Buku Panduan Hak Kekayaan Intelektual (Pertanyaan \& Jawabannya), Direktorat Jenderal HKI, Jakarta, 2000,

Helianti Hilman. Manfaat Perlindungan Terhadap Karya Intelektual pada Sistem HaKI. Disampaikan pada Lokakarya Terbatas tentang "Masalah-masalah Kepailitan dan Wawasan Hukum Bisnis Lainnya". 10-11 Februari 2004. Jakarta, 2004.

M. Yahya Harahap. Tinjauan Merek Secara Umum dan Hukum Merek di Indonesia Berdasarkan Undang-Undang Nomor 19 Tahun 1992, Citra Aditya Bakti, Bandung, 1996.

Muhammad Djumhana, Perkembangan Doktrin dan Teori Perlindungan Hak Kekayaan Intelektual, Citra Aditya Bakti, Bandung, 2006.

O.K. Saidin, Aspek Hukum Hak Kekayaan Intelektual (Intellectual Property Right), Cetakan Keempat, Raja Grafindo Persada, Jakarta, 2004.

Rachmadi Usman. Hukum Hak atas Kekayaan Intelektual, Perlindungan dan Dimensi Hukumnya di Indonesia, Alumni, Bandung, 2003.

Sonny Keraf, Etika Bisnis - Membangun Citra Bisnis Sebagai Profesi Luhur, Yogyakarta, Kanisius, 1998.

Sudargo Gautama dan Rizawanto Winata, Hukum Merek Indonesia, Citra Aditya Bakti, Bandung, 1993. 


\section{B. Jurnal}

Rifky Ardian Nugroho, Budi Santoso, Siti Mahmudah. 2016. Perlindungan Hukum Pemegang Hak Merek Dagang Terkenal Asing (Well Known Mark) Dari Tindakan Passing Off (Studi Sengketa GS Atas Nama GS Yuasa Corporation). Semarang: Diponegoro Law Journal. Volume 5, Nomor 3, Tahun 2016.

Mieke Yustia Ayu Ratna Sari. 2014. Passing Off Dalam Pendaftaran Merek, Kajian Putusan Mahkamah Agung Nomor 224 K/Pdt.Sus-HKI/2014. Jurnal Yudisial Vol. 7 No. 3 Desember 2014.

Imas Rosidawati Wiradirja, Juli Asril. Model Perlindungan Hak Kekayaan Intelektual Atas Pemalsuan dan Peniruan Merek Melalui Pengawasan Perbatasan Oleh Bea Cukai Dalam Era Perdagangan Bebas. E-Journal Kopertis 4

\section{Peraturan Perundang-Undangan}

Undang-Undang Nomor 5 Tahun 1999 Tentang Larangan Monopoli dan Persaingan Usaha Tidak Sehat

Undang-Undang Nomor 20 Tahun 2016 Tentang Merek

\section{Internet}

Geographical Indications" http://www.wipo.int/aboutip/en/geographical_ind.html, diakses tanggal 8 Juni 2017.

Geograpical Indications" http://www.wto.org/english/tratop_e/trips_e/gi_e.htm, diakses tanggal 8 Juni 2017 